Agnieszka Dudek-Kowalska*

WTL Uniwersytetu Śląskiego, Katowice

\title{
MIŁOSIERDZIE JAKO OIKONOMIA KOŚCIOŁA. NA PODSTAWIE WYBRANYCH TEKSTÓW MAGISTERIUM ECCLESIAE
}

Upływ niespełna czterdziestu lat od czasu ogłoszenia encykliki Dives in misericordia nie zdezaktualizował ogłoszonych tam tez i postulatów. Przeciwnie, wiele ze wskazanych wówczas przez Jana Pawła II zagrożeń cywilizacyjnych pogłębiło się, a na pierwszy plan wysunęła się postępująca alienacja człowieka i osłabienie więzów międzyludzkiej solidarności. Propozycja papieża, by właściwie rozumiane i uzasadnione miłosierdzie uczynić panaceum na problemy dotykające relacje międzyludzkie, jest nadal aktualna. Szczególna rola przypada tu Kościołowi. Jak stwierdził Jan Paweł II w encyklice Dives in misericordia: „Jezus Chrystus ukazał, że człowiek nie tylko doświadcza i «dostępuje» miłosierdzia Boga samego, ale także jest powołany do tego, ażeby sam «czynił» miłosierdzie drugim: «Błogosławieni miłosierni, albowiem oni miłosierdzia dostąpią» (Mt 5,7). Kościół znajduje w tych słowach wezwanie do czynu i stara się «czynić miłosierdzie»" (nr 14).

Tak jak papież Jan Paweł II miał przekonanie, że jego zadaniem jest m.in. podzielenie się ze światem treścią objawień doznanych przez s. Faustynę Kowalską, tak szczególnym zadaniem Kościoła po dzień dzisiejszy staje się pogłębianie i przypominanie nauczania o istocie i skutkach doświadczonego i przyjętego Bożego miłosierdzia. W konsekwencji czynienie miłosierdzia ma stać się podstawą relacji społecznych i źródłem naprawy sposobu funkcjonowania społeczeństw ${ }^{1}$.

* Agnieszka Dudek-Kowalska - doktor teologii dogmatycznej, ukończyła także studia prawnicze w KUL; w centrum jej zainteresowań naukowych pozostaje chrystologia i eklezjologia; e-mail: dudekagnkow@gmail.com; ORCID: 0000-0001-8356-1572.

1 J. Warzeszak, Papież Franciszek świadkiem Bożego miłosierdzia, Warszawskie Studia Teologiczne XXIX,4 (2016), s. 36-74. 
Właściwe rozumienie i praktykowanie miłosierdzia jest wyraźnym wyzwaniem także obecnego czasu. Podkreśla to papież Franciszek od początku swojego pontyfikatu. Oznaczenie przez Jana Pawła II misji Kościoła w perspektywie miłosierdzia jest kluczowe z punktu widzenia potrzeb i wyzwań współczesności.

Celem niniejszego artykułu jest prezentacja wybranych zagadnień dotyczących eklezjalnego i społecznego wymiaru miłosierdzia w nauczaniu Kościoła, głównie pontyfikatu Jana Pawła II jako odpowiedzi na zanikanie więzi braterstwa między ludźmi i sposobu na odbudowanie relacji.

\section{MIŁOSIERDZIE BOŻE W SAKRAMENTACH}

Kościót żyje swoim autentycznym życiem, kiedy wyznaje i glosi miłosierdzie - najwspanialszy przymiot Stwórcy i Odkupiciela - i kiedy ludzi przybliża do Zbawicielowych zdrojów miłosierdzia, których jest depozytariuszem i szafarzem² ${ }^{2}$.

Posługę miłosierdzia, jego szafarstwo względem wszystkich ludzi, postrzega Kościół jako swój szczególny obowiązek rozumiany w kategoriach posługi sakramentalnej. Sakramenty, będące skutecznymi znakami łaski w posłudze Kościoła, jawią się jako wyjątkowe środki przekazu miłosierdzia. To w nich szczególnie uobecnia się miłosierdzie Boże, zakorzenione w owocach misterium paschalnego, aktualizując je dla każdego przyjmującego sakrament. W sposób szczególny sakramentem miłosierdzia jest Kościół, który jako jeden organizm stanowi narzędzie łaski Boga dla świata. W Kościele jako prasakramencie mają szansę na realizację wszystkie sakramenty, czerpiące swą skuteczność z misji i łaski Kościoła.

\section{KOŚCIÓŁ JAKO SAKRAMENT BOŻEGO MIŁOSIERDZIA}

Im bardziej świadomość ludzka, ulegając sekularyzacji, traci poczucie sensu samego słowa „miłosierdzie” - im bardziej, oddalając się od Boga, oddala się od tajemnicy miłosierdzia - tym bardziej Kościół ma prawo i obowiązek odwoływać się do Boga miłosierdzia „wołaniem wielkim”.

Sakramentalność Kościoła jest szczególna. Jej sens sprowadza się m.in. do przedłużenia tajemnicy paschalnej, stanowiącej „szczytowy punkt tego właśnie objawienia i urzeczywistnienia miłosierdzia, które zdolne jest usprawiedliwić człowieka, przywrócić sprawiedliwość w znaczeniu owego zbawczego ładu, jaki

Jan Paweł II, Encyklika „Dives in misericordia” (30.11.1980) [dalej: DiM], nr 13.

3 DiM 15. 
Bóg od początku zamierzył w człowieku, a przez człowieka w świecie"4. Z woli Boga Kościół przekazuje ludziom owoce zbawienia, pośrednicząc w spotkaniu z Bogiem i uobecniając wydarzenia zbawcze. Tym samym Kościół stanowi sakrament Bożej miłości i miłosierdzia ${ }^{5}$ czy, jak chcą inni, prasakrament - źródło innych sakramentów, znak zbawczej obecności Boga wśród ludzi, społeczność umożliwiającą kontakt z Jego miłością-miłosierdziem ${ }^{6}$.

Zbawcza sakramentalność Kościoła powinna być też rozumiana jako sakramentalność w posłudze i uobecnianiu miłosierdzia Bożego. Kościół Chrystusowy stanowi owoc miłosierdzia i jego zadaniem jest nie tylko głoszenie, wyznawanie i przywoływanie miłosierdzia Boga, ale przede wszystkim jego urzeczywistnianie i uobecnianie ${ }^{7}$.

Sakramentalność Kościoła jest szczególnym sposobem na urzeczywistnianie jego misji miłosierdzia. Dzieje się tak z uwagi na nadprzyrodzony i „darmowy” charakter łaski miłosierdzia, która drogą posługi Kościoła pragnie się objawiać w świecie. Kościół musi być świadomy, że jako znak i owoc miłosierdzia, jako jego szczególny i pierwszy sakrament w pierwszej kolejności powołany jest do urzeczywistniania miłosierdzia. „Uobecniając w swym zbawczym pośrednictwie sakramentalnym samego Chrystusa, Kościół przyczynia się do tego, że Miłosierdzie Boże ogarnia wiernych w każdym z siedmiu sakramentów, w których przez akty Kościoła działa osobowo uwielbiony Chrystus w mocy Ducha [...]”8.

\section{EUCHARYSTIA JAKO ŹRÓDŁO BOŻEGO MIŁOSIERDZIA}

Sam obrzęd eucharystyczny sprawowany na pamiątkę Tego, który w swym mesjańskim posłannictwie objawił nam swego Ojca przez słowo i krzyż, świadczy o tej niewyczerpalnej miłości, mocą której pragnie On stale łączyć się z nami i jednoczyć, wychodząc na spotkanie wszystkich ludzkich serc ${ }^{9}$.

\section{DiM 7.}

5 L. Balter, Kościót jako „,sakrament” Miłosierdzia Bożego, w: W Miłosierdziu Bożym ku nowej ewangelizacji. V Kongres ku czci Miłosierdzia Bożego. 9-11 kwietnia 1999, Częstochowa-Dolina Miłosierdzia - Księża Pallotyni, Ząbki 1999, s. 25.

$6 \quad$ F. Greniuk, Mitosierdzie Boże w sakramencie pojednania, w: Jan Pawet II. Dives in misericordia. Tekst i komentarze, red. S. Nagy, Lublin 1983, s. 197.

7 L. Balter, Kościót jako ,, sakrament..., s. 35; zob. także: tenże, Kościót jako sakrament Bożego miłosierdzia, Kolekcja Communio 15, red. L. Balter, S. Dusza, A. Piętka, Poznań 2003, s. 151-173.

8 M. Kowalczyk, Sakramentologia, w: Dogmatyka w perspektywie Bożego miłosierdzia, red. K. Góźdź, K. Guzowski, Lublin 2010, s. 206-207.

9 DiM 13. 
Pojęcie „sakrament miłosierdzia” odnoszone jest zazwyczaj do sakramentu pokuty i pojednania ${ }^{10}$. Określenie to jednak w pełni odpowiada również sakramentowi Eucharystii. Już w konstytucji o Liturgii Świętej Soboru Watykańskiego II Eucharystia nazwana jest wprost sakramentem miłosierdzia ${ }^{11}$. Sakramentem miłosierdzia nazwał ją również Paweł VI w encyklice Mysterium fidei, powtarzając słowa konstytucji soborowej Sacrosanctum concilium ${ }^{12}$. Jan Paweł II tym określeniem nazwał Eucharystię w encyklice Dominum et vivificantem ${ }^{13}$, a tuż przed śmiercią napisał, że „nic tak jak eucharystyczna obecność Pana nie uobecnia dzieła miłosierdzia, które dokonało się przez Krzyż i Zmartwychwstanie"14.

Eucharystia jest sakramentem miłosierdzia, gdyż każdorazowo ponawia mękę i śmierć Chrystusa, które jako „ofiara pojednania” pochodzą z inicjatywy miłosiernego Ojca. Tym samym przybliża nas ona do miłości miłosiernej objawionej w tajemnicy paschalnej, przez którą Jezus ocalił człowieka i ofiarował mu nowe życie w Bogu ${ }^{15}$.

Eucharystia buduje Kościół, o czym niejednokrotnie wspomina Magisterium Kościoła, w tym encyklika Ecclesia de Eucharistia ${ }^{16}$. Benedykt XVI w swojej pierwszej encyklice poświęconej miłości Bożej napisał:

W samym „kulcie”, w komunii eucharystycznej zawiera się bycie miłowanym i jednocześnie, z mojej strony, miłowanie innych. Eucharystia, która nie przekłada się na miłość konkretnie praktykowaną, jest sama w sobie fragmentaryczna ${ }^{17}$.

W dokumencie dotyczącym Eucharystii, wydanym przez Oficjalny Komitet Obchodów Roku Jubileuszowego 2000, sakrament ten jest postrzegany jako

10 Listy Ojca Świętego Jana Pawła II do kapłanów na Wielki Czwartek roku 2001 i 2002.

11 „Zbawiciel nasz podczas Ostatniej Wieczerzy, tej nocy, kiedy został wydany, ustanowił Eucharystyczną Ofiarą Ciała i Krwi swojej, aby w niej na całe wieki, aż do swego przyjścia, utrwalić Ofiarę Krzyża i tak umiłowanej Oblubienicy Kościołowi powierzyć pamiątkę swej Męki i Zmartwychwstania: sakrament miłosierdzia [podkr. - A.D.-K.], znak jedności, węzeł miłości, ucztę paschalną, w której pożywamy Chrystusa, w której dusza napełnia się łaską i otrzymuje zadatek przyszłej chwały” (Sobór Watykański II, Konstytucja o Liturgii Świętej ,, Sacrosanctum concilium" (6.12.1963), $\mathrm{nr} 47)$.

12 Tamże; Paweł VI, Encyklika „Mysterium fidei” (3.09.1965), nr 1.

13 Jan Paweł II, Encyklika „Dominum et vivificantem” (18.05.1986) [dalej: DV], nr 62. Benedykt XVI nazywa Eucharystię w sposób zbliżony: sakramentem miłości. Zob. Benedykt XVI, Eucharystia musi być centrum waszego życia. 21 sierpnia. Msza św. na zakończenie Światowego Dnia Młodzieży, L'Osservatore Romano [wyd. polskie] 26,10 (2005), s. 26-28.

14 Telegram do wiernych gromadzących się w sanktuarium w krakowskich Łagiewnikach przed Świętem Miłosierdzia Bożego w 2005 r., cyt. za: M. Kowalczyk, Sakramentologia, w: Dogmatyka w perspektywie..., s. 217.

15 DiM 13.

16 Jan Paweł II, Encyklika „Ecclesia de Eucharistia” [dalej: EdE], nr 1.

17 Benedykt XVI, Encyklika „Deus caritas est” (25.12.2005), nr 14. 
źródło miłości ${ }^{18}$. Miłość ta płynie od Chrystusa i uzdalnia do przeżycia miłości w swoim życiu. Na pierwszy plan wysuwa się w tym względzie przebaczenie, do którego zobowiązany jest każdy uczestnik Eucharystii. Sakrament ten wychowuje do miłosierdzia, gdyż domaga się pojednania między ludźmi ${ }^{19}$.

W ostatniej swej encyklice Jan Paweł II nazwał Eucharystię tajemnicą miłosierdzia, włączając ją w zbawczą tajemnicę odkupienia:

Gdy Kościół sprawuje Eucharystię, pamiątkę śmierci i zmartwychwstania swojego Pana, to centralne wydarzenie zbawienia staje się rzeczywiście obecne i „dokonuje się dzieło naszego Odkupienia". Ofiara ta ma do tego stopnia decydujące znaczenie dla zbawienia rodzaju ludzkiego, że Jezus złożył ją i wrócił do Ojca, dopiero wtedy, gdy zostawił nam środek umożliwiajacy uczestnictwo w niej, tak jakbyśmy byli w niej obecni. W ten sposób każdy wierny może w niej uczestniczyć i korzystać z jej niewyczerpanych owoców. [...] Pragnę raz jeszcze przypomnieć tę prawdę, drodzy Bracia i Siostry, adorując razem z wami tę tajemnicę: tajemnicę wielką, tajemnicę miłosierdzia. Cóż większego Jezus mógł uczynić dla nas? Prawdziwie, w Eucharystii objawia nam miłość, która posuwa się „aż do końca” (por. J 13,1) - miłość, która nie zna miary ${ }^{20}$.

\section{SAKRAMENT POKUTY JAKO DAR BOŻEGO MIŁOSIERDZIA}

Drogę zaś do tego spotkania i zjednoczenia [w sakramencie Eucharystii - dop. A.D.-K.] toruje każdemu - nawet wówczas, gdy ciążą na nim wielkie winy - sakrament pokuty i pojednania. W sakramencie tym każdy człowiek może w sposób szczególny doświadczyć miłosierdzia, czyli tej miłości, która jest potężniejsza niż grzech ${ }^{21}$.

Posługa sakramentem pokuty i pojednania stanowi jedno z podstawowych zadań Kościoła, a sprowadza się do jednania zagubionych z Ojcem miłosierdzia i umożliwiania im powrotu do Niego ${ }^{22}$. Sakrament ten stanowi szczególny znak

18 Eucharystia sakrament nowego życia. Oficjalny dokument Papieskiego Komitetu Obchodów Wielkiego Jubileuszu roku 2000, red. Komisja Teologiczno-Historyczna Wielkiego Jubileuszu Roku 2000, Katowice 2000, s. 178.

19 Tamże; Jan Paweł II, Adhortacja ,,Reconciliatio et paenitentia” (29.10.1983) [dalej: ReP], nr 7.

20 EdE 11.

21 DiM 13.

22 Jan Paweł II, List apostolski w formie motu proprio „Misericordia Dei” o niektórych aspektach sprawowania Sakramentu Pokuty, L'Osservatore Romano [wyd. polskie] 23,6 (2002), s. 4-5; por. tenże, Bulla „Incarnationis mysterium” (29.11.1998); tenże, Sakrament spowiedzi darem miłosierdzia Bożego. Przestanie papieskie do kard. Williama Wakefielda Bauma, L'Osservatore Romano [wyd. polskie] 21,6 (2000), s. 5-7, nr 1. 
Bożego miłosierdzia w stosunku do grzesznego człowieka ${ }^{23}$. Podobnie jak Eucharystię Magisterium Kościoła nazywa go wprost „sakramentem miłosierdzia”24. To właśnie w sakramencie pokuty i pojednania odsłania się ten wymiar miłosierdzia, który jest reakcją na grzech człowieka. Już Sobór Watykański II w konstytucji dogmatycznej o Kościele stwierdził, że w sakramencie tym wierni „otrzymują od miłosierdzia Bożego przebaczenie zniewagi wyrządzonej Bogu i równocześnie jednają się z Kościołem, któremu grzesząc zadali ranę, a który przyczynia się do ich nawrócenia miłością, przykładem i modlitwą "25.

$\mathrm{Na}$ temat istoty miłosierdzia obecnego $\mathrm{w}$ sakramencie pokuty i pojednania ważne słowa odnajdujemy w encyklice Dives in misericordia. Jan Paweł II stwierdził w niej:

Właśnie dlatego, że w świecie, który Bóg tak umiłował, ,że Syna swego Jednorodzonego dał" tu (J 3,16), istnieje grzech, Bóg, który ,jest miłością" (1 J 4,16), nie może objawiać się inaczej niż jako miłosierdzie. Miłosierdzie odpowiada nie tylko najgłębszej prawdzie owej miłości, jaką jest Bóg (i która jest Bogiem), ale także całej wewnętrznej prawdzie człowieka i świata, który jest jego doczesną ojczyzną. Miłosierdzie samo w sobie, jako doskonałość nieskończonego Boga, jest również nieskonczone. Nieskończona więc i niewyczerpana jest też gotowość Ojca w przyjmowaniu synów marnotrawnych wracających do Jego domu. Nieskończona jest gotowość i moc przebaczania, mając swe stałe pokrycie w niewysłowionej wartości ofiary Syna. Żaden grzech ludzki nie przewyższa tej mocy ani jej nie ogranicza. Ograniczyć ją może tylko od strony człowieka brak dobrej woli, brak gotowości nawrócenia, czyli pokuty, trwanie w oporze i sprzeciwie wobec łaski i prawdy, a zwłaszcza wobec świadectwa krzyża i zmartwychwstania Chrystusowego ${ }^{26}$.

Zadanie Kościoła w zakresie służby miłosierdziu obecnemu w sakramencie pokuty i pojednania polega zatem na umożliwieniu człowiekowi otrzymania

23 C. Krakowiak, Miłosierdzie Boże w liturgii sakramentu pojednania, w: Jan Pawet II. Dives in misericordia..., s. 205-206.

24 Listy Ojca Świętego Jana Pawła II do kapłanów na Wielki Czwartek roku 2001 i 2002.

25 Sobór Watykański II, Konstytucja dogmatyczna o Kościele „Lumen gentium” (21.11.1964) [dalej: KK], nr 11. Zachętę do poświęcenia szczególnej uwagi i troski w zakresie sakramentu pokuty jako jedną z głównych misji Kościoła odnajdujemy również w nowszych wypowiedziach Magisterium, m.in. w Novo millennio ineunte (6.01.2001) [dalej: NMI] oraz w Misericordia Dei. Por. KKK 1440-1449.

26 DiM 13. W encyklice Redemptor hominis Jan Paweł II zawężająco, prawdopodobnie ze względu na tematykę poruszaną w encyklice, traktuje miłosierdzie właśnie jako aspekt miłości zwyciężającej grzech, zawsze gotowej przebaczać. Zob. RHm 1, 9. 
łaski przebaczenia i doświadczenia nawrócenia. W łasce tej wyraża się najpełniej miłosierdzie Boże, a człowiek, któremu odpuszcza się grzechy i który dostępuje przebaczenia, odkrywa miłosierne oblicze Boga, będącego Ojcem ${ }^{27}$.

W sakramencie pokuty i pojednania, według nauczania Kościoła, odsłania się także ten wymiar miłosierdzia, który odpowiada treści słowa „zbawienie”28. Motywem wyjścia Boga z inicjatywą zbawczą ku człowiekowi było miłosierdzie. Miłosierdzie Boże, stanowiące odpowiedź i przeciwstawienie grzechowi człowieka, jest owym mysterium pietatis $(1 \mathrm{Tm} 3,15)$ - tajemnicą pobożności rozumianej jako moc nawrócenia i pojednania ${ }^{29}$.

W teologicznym i pastoralnym wprowadzeniu do Obrzędów sakramentu pokuty czytamy m.in.: „Bóg Ojciec okazał swoje miłosierdzie przez Chrystusa, jednając ze sobą wszystko, co jest na ziemi i co jest w niebie, przywracając pokój przez Jego krew na krzyżu" ${ }^{30}$. W formule rozgrzeszenia sakramentalnego Bóg, sprawca pojednania, został nazwany Ojcem miłosierdzia, a jako źródło pojednania grzesznika z Bogiem zostaje wskazane Boże miłosierdzie ${ }^{31}$. Jan Paweł II, rozpoczynając encyklikę Dives in misericordia, odwołał się do słów: „Bóg, będąc bogaty w miłosierdzie, przez wielką swą miłość, jaką nas umiłował, i to nas, umarłych na skutek występków, razem z Chrystusem przywrócił do życia (Ef 2,4-5)"32. Obydwa teksty wskazują na Jezusa Chrystusa jako narzędzie uobecnienia miłosierdzia Ojca, a szczytowym momentem tego dzieła była tajemnica paschalna ${ }^{33}$.

W Obrzędach sakramentu pokuty czytamy także, że miłosierdzie Boże jest większe od wszystkich naszych grzechów i to nim kieruje się Bóg, ciągle wzywając ludzi do siebie ${ }^{34}$; że Duch Święty może oświecić grzesznika, aby poznał nie tylko swoje grzechy, ale i ogrom Bożego miłosierdzia ${ }^{35}$. W sformułowaniach dotyczących okazania żalu za grzechy dominują prośby o zmiłowanie, litość,

27 „I dlatego też Kościół wyznaje i głosi nawrócenie. Nawrócenie do Boga zawsze polega na odnalezieniu miłosierdzia, czyli owej miłości, która cierpliwa jest i łaskawa (por. 1 Kor 13,4) na miarę Stwórcy i Ojca - miłości, której «Bóg i Ojciec Pana naszego Jezusa Chrystusa» (2 Kor 1,3) jest wierny aż do ostatecznych konsekwencji w dziejach przymierza $\mathrm{z}$ człowiekiem: aż do krzyża - czyli do śmierci i zmartwychwstania swojego Syna. Nawrócenie do Boga jest zawsze owocem «odnalezienia» tego Ojca, który bogaty jest w miłosierdzie» (DiM 13).

ReP 22.

30 Obrzędy sakramentu pokuty (2.12.1973) [dalej: OP], nr 1.

31 OP 19, 46.

$32 \quad$ DiM 1.

33 Por. DiM 1-2, 7; OP 1.

34 OP 25a.

35 OP $42 \mathrm{~b}$. 
stanowiące odpowiednik miłosierdzia ${ }^{36}$. Uzyskanie rozgrzeszenia winno prowadzić do wychwalania przez człowieka miłosierdzia Bożego ${ }^{37}$, a właściwym zadośćuczynieniem za grzechy winny być czyny miłosierdzia ${ }^{38}$. Według Obrzędów sakramentu pokuty poszczególne elementy, warunki dobrej spowiedzi, powinny mieć odniesienie do Bożego miłosierdzia ${ }^{39}$.

\section{WYOBRAŹNIA MIŁOSIERDZIA}

Potrzebna jest dziś nowa „,wyobraźnia miłosierdzia”, której przejawem będzie nie tyle i nie tylko skuteczność pomocy, ale zdolność bycia bliźnim dla cierpiącego człowieka, solidaryzowania się z nim, tak aby gest pomocy nie był odczuwany jako poniżająca jałmużna, ale jako świadectwo braterskiej wspólnoty dóbrit ${ }^{40}$.

Dla urzeczywistnienia miłosierdzia jako przedmiotu działalności Kościoła potrzebna jest „wyobraźnia miłosierdzia”. Sformułowanie to, które utrwalił w pamięci wiernych Jan Paweł II, prowadzi do wniosku, że postawa autentycznego miłosierdzia domaga się nieustannej gotowości, wyprzedzania niejako potrzeb, którym możemy zaradzić. Wyobraźnia miłosierdzia winna być nieustannie kształtowana i pielęgnowana. Owocnie służyć ma temu kształtowanie w sobie postawy solidarności z innymi ludźmi i odnawiania osobistego rozumienia miłosierdzia, pojmowanego indywidualnie i społecznie ${ }^{41}$.

Zobowiązanie do miłosierdzia w teologicznej interpretacji znajduje swoje uzasadnienie w Bożym synostwie, które za przyczyną Jezusa otrzymał każdy człowiek (Ef 1,4), oraz w braterstwie z Chrystusem. Skoro Chrystus, nasz Brat, był Wcieleniem Miłosierdzia, tzn. że zadaniem Jego braci, a więc w pierwszej kolejności Kościoła, jest świadczenie miłosierdzia ${ }^{42}$.

\footnotetext{
OP $45 \mathrm{c}$.

OP 47.

OP 18

39 Np. rachunek sumienia i wyznanie grzechów. „To wewnętrzne badanie serca i zewnętrzne oskarżenie powinno się odbywać w świetle Bożego miłosierdzia" (OP 6b). Na temat miłosierdzia w posłudze spowiednika zob. S. Mojek, Miłosierdzie Boże w sprawowaniu sakramentu pojednania, w: Miłosierdzie w postawie ludzkiej, red. W. Słomka, Lublin 1989, s. 129-134.

41 Por. J. Nowak, Podstawy ,, wyobraźni miłosierdzia” w nauczaniu Ojca Świętego Jana Pawła II, Ruch Biblijny i Liturgiczny 2 (2006), s. 125-137.

42 S. Padewski, Droga Kościoła - droga miłosierdzia, w: Tajemnica Bożego miłosierdzia w charyzmacie mariańskim, red. J. Kumala, Licheń 2004, s. 96.
}

40 NMI 50. 


\section{SOLIDARNOŚĆ Z POTRZEBUJĄCYMI}

Miłość ta [objawiona przez Chrystusa - dop. A.D.-K.] w sposób szczególny daje o sobie znać w zetknięciu z cierpieniem, krzywdą, ubóstwem, w zetknięciu z całą historyczną „ludzką kondycją”, która na różne sposoby ujawnia ograniczoność i słabość człowieka, zarówno fizyczną, jak i moralną. Właśnie ten sposób i zakres przejawiania się miłości nazywa się w języku biblijnym „miłosierdziem”43.

Miłosierdzie, stanowiące odpowiedź Kościoła na wypowiedziane w Kazaniu na górze wezwanie Chrystusa do świadczenia miłosierdzia, od samego początku jego istnienia przejawiało się w trosce o potrzebujących. W tym celu Kościół ustanawiał posługi, tworzył specjalne miejsca opieki, organizował pomoc medyczną. Miłosierdzie świadczone przez Kościół od samego początku nie było pojmowane jako litość, ale jako służba ${ }^{44}$. W kontakcie z potrzebującymi, z doświadczającymi różnorakiej biedy Kościół urzeczywistniał prawdziwe miłosierdzie, solidaryzując się z tymi, którym je okazywał ${ }^{45}$.

Mimo że troska Kościoła zawsze skierowana była ku cierpiącym, myśl Kościoła okresu posoborowego zwróciła uwagę na rolę cierpiących w świadczeniu miłosierdzia. W licznych wypowiedziach Jan Paweł II podkreślił, że cierpiący i wszyscy potrzebujący są nie tylko obiektem posługi Kościoła, ale czynnym podmiotem miłosierdzia i podporą w okazywaniu duchowej owocności cierpienia ${ }^{46}$. Osoby cierpiące mogą stać się nosicielami łaski, przedłużeniem Chrystusa, re-

$43 \quad$ DiM 3.

44 Zinstytucjonalizowanie świadczenia dzieł miłosierdzia ma w chrześcijaństwie bogatą tradycję. Już w starożytnych gminach apostolskich krystalizowały się pierwsze formy zinstytucjonalizowanej posługi charytatywnej. Powołano urząd diakona (Dz 6,16). Później pojawiły się instytucje tworzone przez biskupów lub przy poszczególnych kościołach i klasztorach, pomagające podróżnym, chorym, trędowatym, starcom, sierotom i innym. Na początku średniowiecza opiekę nad biednymi przejęły parafie. Sobór Trydencki zobowiązał biskupów do czuwania nad szpitalami i różnymi fundacjami na rzecz biednych. To wówczas powstały nowe zakony do opieki nad chorymi (kamilianie, bonifratrzy), instytucje dobroczynne św. Wincentego à Paulo (lazaryści, szarytki). W 1924 r. została powołana międzynarodowa centrala katolickich organizacji dobroczynnych Caritas Catholica. Po przerwie spowodowanej II wojną światową jej działalność przejęła w 1951 r. Caritas Internationalis w randze Sekretariatu Stolicy Apostolskiej. W 1989 r. episkopat Polski reaktywował zakazaną w czasie komunizmu działalność Caritas Polska. Por. S. Padewski, Droga Kościoła - droga ..., s. 109-110.

45 Jan Paweł II, Pochylać się nad cierpiacym człowiekiem. Anioł Pański 24 sierpnia 1980 r., w: Krzyż znakiem naszej wiary i nadziei. Jan Pawet II o cierpieniu Chrystusa i człowieka. 1978 - szesnasty października - 1986, red. W. Murawiec, M. Rudyk, Kalwaria Zebrzydowska 1986, s. 237; Benedykt XVI, Orędzie na Wielki Post 2006, https://opoka.org.pl/biblioteka/W/WP/benedykt_xvi/przemowienia/wpost2006kep_29092005.html (dostęp: 15.04.2019).

Por. np. listy Jana Pawła II kierowane do chorych. 
alizatorami miłosierdzia dla siebie i dla innych. Chorzy i cierpiący jako ci, którzy dopełniają w swym ciele zbawczych udręk Chrystusowych (Kol 1,24), sami rozpowszechniają miłość miłosierną, gdyż to ona właśnie jest ich powołaniem ${ }^{47}$. Cierpienie ludzkie stanowi swego rodzaju zaproszenie do solidarności z Chrystusem cierpiącym, a zarazem do udziału w tajemnicy zbawienia:

Cierpienia ludzkie są wspólnym dziedzictwem wszystkich: każdy może wnieść swój osobisty wkład do Odkupienia, które, aczkolwiek dokonało się raz na zawsze, potrzebuje tego tajemniczego dopełnienia ofiarą dźwigania tego wielkiego ciężaru, którym jest zło i ból ludzkości ${ }^{48}$.

Jan Paweł II widział w świadomym ludzkim cierpieniu niewypowiedziane bogactwo miłosierdzia rozlanego na rodzaj ludzki dla zbilansowania grzechów. Uważał, że wszelkie cierpienie jest powołaniem, aby przyjąć jego ciężar i wraz z Chrystusem ofiarować je za zbawienie własne i innych, że jest źródłem siły podobnej do tej, która płynęła z Chrystusowego krzyża ${ }^{49}$.

Jednocześnie w miłosierdziu przejawiającym się w postawie cierpiących i potrzebujących Jan Paweł II widział miejsce pełnej realizacji „wymienności” miłosierdzia, przez którą dający miłosierdzie jest jednocześnie obdarowanym. Ta wymienność jest synonimem prawdziwej solidarności z potrzebującymi, gdzie nie ma miejsca na nierówność stron. Członkowie Kościoła świadczący miłosierdzie potrzebującym są równocześnie najpełniej obdarowani miłosierdziem, które zapodmiotawia się w postawie świadomego przyjęcia cierpienia ${ }^{50}$.

\section{RELACYJNOŚĆ MIŁOSIERDZIA}

Miłość miłosierna we wzajemnych stosunkach ludzi nigdy nie pozostaje aktem czy też procesem jednostronnym. Nawet $\mathrm{w}$ wypadkach, w których wszystko zdawałoby się

47 Jan Paweł II, Jesteście na wage złota. Stowa Jana Pawła II przed katedra, Częstochowa 6 czerwca 1979 r., Chrześcijanin w Świecie 11,8 (1979), s. 134-135; S. Padewski, Droga Kościoła - droga..., s. 105-106.

48 Jan Paweł II, Solidarność z Chrystusem cierpiacym. Przemówienie do Kolegium Kardynałów Kurii Rzymskiej z dnia 23 grudnia 1982 r., w: Krzyż znakiem..., s. 172; por. tenże, List apostolski ,Salvifici doloris” (11.02.1984), nr 27; tenże, Kontemplujmy przykład Jezusa - Boskiego Samarytanina. Orędzie na VIII Światowy Dzień Chorego 2000 r. (6.08.1999), https://opoka. org.pl/biblioteka/W/WP/jan_pawel_ii/ przemowienia/chory2000_06081999.html, nr 7 (dostęp: 30.12.2019).

49 Jan Paweł II, Cierpienie nie jest nigdy bezużyteczne. Homilia z dnia 3 września 1983 r. ze szpitala Villa Albani, L'Osservatore Romano [wyd. polskie] 4,9 (1983), s. 27.

50 S. Padewski, Droga Kościoła - drogą..., s. 106. 
wskazywać na to, że jedna strona tylko obdarowuje, daje - a druga tylko otrzymuje, bierze [...], w istocie rzeczy zawsze również i ta pierwsza strona jest obdarowywana. A w każdym razie także i ten, który daje, może bez trudu odnaleźć siebie w pozycji tego, który otrzymuje, który zostaje obdarowany, który doznaje miłości miłosiernej, owszem, doznaje miłosierdzia ${ }^{51}$.

Miłosierdzie, którym ma żyć Kościół i wszyscy jego członkowie, stanowi najpełniejszą zasadę życia chrześcijańskiego. W nim bowiem zawiera się całokształt i kwintesencja nauki, którą przekazał Chrystus - rdzeń Jego orędzia mesjańskiego. Wbrew poglądom dostrzegającym w miłosierdziu jedynie proces jednostronny i upokarzający człowieka, któremu świadczy się miłosierdzie, Jan Paweł II dokonał jego reinterpretacji. Uznał, że miłosierdzie stanowi narzędzie wzajemnej wymiany pomiędzy dającym a przyjmującym je. Miłosiernym jest nie tylko ten, kto je świadczy, ale i ten, kto przyjmuje ofiarowane mu miłosierdzie ${ }^{52}$. Dotyczy to również sytuacji, kiedy z pozoru wydawać by się mogło, że miłosierdzie jest świadczone wyłącznie przez jedną ze stron, jak ma to miejsce w przypadku pracy lekarzy, nauczycieli, roli rodziców itp..$^{53}$.

Obiegowe rozumienie miłosierdzia zakłada dystans, jaki musi rodzić się między „dobro-czyńcą” i „dobro-biorcą”. Stąd miłosierdzie jest często traktowane jako uwłaczające przyjmującym je i nie może być uznawane za budulec zdrowych relacji społecznych. Jan Paweł II zadał jednak kłam tym poglądom, konstruując personalistyczną koncepcję miłosierdzia jako relacji wymiany dóbr. Wyobraźnia miłosierdzia, której konieczność widział Jan Paweł II, wyraża się m.in. w naprawie rozumienia samego miłosierdzia. Przemiana duchowa świata nie będzie mogła dokonać się, jeśli miłosierdzie będzie interpretowane według dawnych wzorów, kiedy mylono je z filantropią, litością czy współczuciem ${ }^{54}$.

\section{RELACJA MIŁOSIERDZIA I SPRAWIEDLIWOŚCI}

[...] sądy o miłosierdziu nie dostrzegają tego podstawowego związku pomiędzy miłosierdziem a sprawiedliwością, o jakim mówi cała tradycja biblijna, a nade wszystko mesjańskie posłannictwo Jezusa Chrystusa. Autentyczne miłosierdzie jest jakby głębszym źródłem sprawiedliwości ${ }^{55}$.

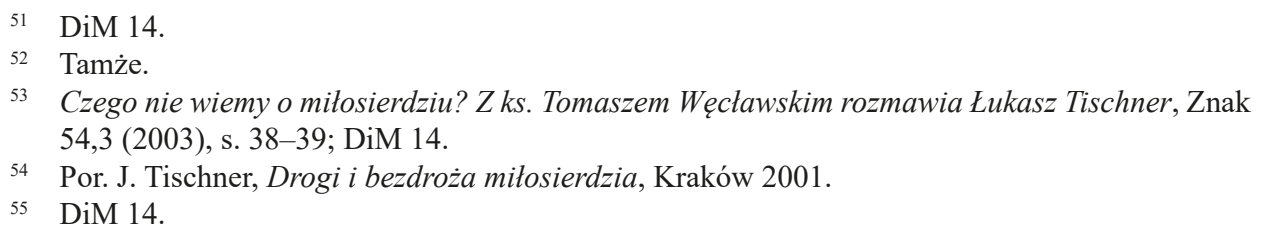


Encyklika Dives in misericordia zawiera znamienne sformułowanie:

Autentycznie chrześcijańskie miłosierdzie jest zarazem jakby doskonalszym wcieleniem „zrównania” pomiędzy ludźmi, a więc także i doskonalszym wcieleniem sprawiedliwości, o ile ta w swoich granicach dąży również do takiego zrównania. Jednakże „zrównanie” przez sprawiedliwość zatrzymuje się w kręgu dóbr przedmiotowych związanych z człowiekiem, podczas gdy miłość i miłosierdzie sprawiają, iż ludzie spotykają się ze sobą w samym tym dobru, jakim jest człowiek z właściwą mu godnością. Równocześnie „zrównanie” ludzi przez miłość „łaskawą i cierpliwą” (por. 1 Kor 13,4) nie stanowi zatarcia różnic: ten, kto daje - daje tym bardziej, gdy równocześnie czuje się obdarowany przez tego, kto przyjmuje jego dar; ten zaś, kto umie przyjąć ze świadomością, że i on również przyjmując, świadczy dobro, ze swej strony służy wielkiej sprawie godności osoby, która najgłębiej może jednoczyć ludzi pomiędzy sobą ${ }^{56}$.

Zestawienie pojęć „miłosierdzie” i „sprawiedliwość” przez Jana Pawła II w odniesieniu do sytuacji współczesnego człowieka prowadzi do wniosku, że problemem naszych czasów jest narastający proces zmiany samego rozumienia sprawiedliwości. Jest ona coraz bardziej pojmowana bezosobowo i formalnie, traktuje się ją jedynie jako zgodność z obowiązującym prawem.

Jan Paweł II zakwestionował takie rozumienie pojęcia „sprawiedliwości”, które nie zawiera odniesienia do miłosierdzia. Potocznemu rozumieniu sprawiedliwości papież przeciwstawił biblijne jej znaczenie. Biblijny ideał sprawiedliwości koncentruje się na człowieku, a nie na prawie: sprawiedliwy jest najpierw Bóg - a Jego sprawiedliwością jest właśnie miłosierdzie. W dalszej kolejności za sprawiedliwego jest uważany ten człowiek, który jest miłosierny. W Biblii miłosierdzie jest sercem sprawiedliwości. Tylko miłosierdzie jest sprawiedliwe wobec człowieka ${ }^{57}$.

Relacja miłosierdzia do sprawiedliwości w stosunkach społecznych w ujęciu Jana Pawła II wywodzi się z koncepcji miłosierdzia jako procesu dwustronnego. Taka koncepcja miłosierdzia nie godzi w ideę sprawiedliwości, nie przeciwstawia się jej, ale stanowi jej konieczne dopełnienie. Nie brak w dziejach ludzkich przykładów, kiedy idea sprawiedliwości była wypaczana i stawała się synonimem okrucieństwa, braku tolerancji, braku wolności, a wręcz jakiejś obiektywnej niesprawiedliwości. „Autentyczne miłosierdzie jest jakby głębszym źródłem sprawiedliwości"'58 - czytamy w Dives in misericordia. Miłosierdzie pozwala sprawiedliwości społecznej oderwać się od kręgu dóbr przedmiotowych i wznieść się do poziomu dobra personalnego, do godności człowieka.

Tamże.

57 J. Słomka, Boże miłosierdzie, Gość Niedzielny 80,17 (2003), s. 9.

58

DiM 14 
Miłosierdzie tak pojęte i zdefiniowane przez papieża nie niweczy wymagań sprawiedliwości. Wręcz przeciwnie, domaga się naprawienia krzywd, nie pozostaje obojętne na zło, niesprawiedliwość. Jeśli jego elementem jest braterska solidarność, to tym bardziej przeciwstawia się każdej niesprawiedliwości. Miłosierdzie jednak pozbawia sprawiedliwość ostrza odwetu i wypełnia ją przebaczeniem. Odkrywa jej nowe, pełniejsze oblicze, znane już z kart Biblii, gdzie sprawiedliwość oznacza równocześnie pełnię miłości, zbawienia, pojednania, miłosierdzia.

Paradoksalnie w nauczaniu Kościoła sprawiedliwość może nią być tylko wtedy, kiedy opiera się na zasadzie dobrze pojętego przebaczenia. Oczywiście, aby pełne przebaczenie mogło zaistnieć, potrzebne jest spełnienie wszelkich wymogów sprawiedliwości. Tym niemniej przebaczenie w ramach sprawiedliwości pozwala urzeczywistnić pojednanie i zbudować faktyczną cywilizację miłości.

Wzajemna relacja miłości, miłosierdzia i sprawiedliwości według oceny Jana Pawła II przedstawia się następująco: miłość ,staje się miłosierdziem wówczas, gdy wypada jej przekroczyć ścisłą miarę sprawiedliwości" ${ }^{59}$. Miłość jest większa niż sprawiedliwość: ,Jest większa w tym znaczeniu, że jest pierwsza i bardziej podstawowa. Miłość niejako warunkuje sprawiedliwość, a sprawiedliwość ostatecznie służy miłości. Ów prymat, pierwszeństwo miłości w stosunku do sprawiedliwości [...] ujawnia się właśnie poprzez miłosierdzie"60.

Miłosierdzie w stosunkach społecznych nie niesie w sobie nic z upokorzenia, nie jest filantropią, nie jest jednorazowym gestem. Wypełnia sprawiedliwość, która bez miłosierdzia zmierza w kierunku legalizmu i uderza w godność człowieka.

\section{CZYNY MIŁOSIERDZIA}

Kościół stara się również czynić miłosierdzie ludziom przez ludzi, widząc w tym nieodzowny warunek zabiegów o lepszy, „bardziej ludzki” świat dnia dzisiejszego i jutrzejszego ${ }^{61}$.

Miłosierdzie prawdziwie chrześcijańskie, do którego wezwany jest Kościół i wszyscy jego członkowie, to takie, które jest wynikiem doświadczenia Bożego miłosierdzia, a zarazem pozostaje kontynuacją miłosierdzia Chrystusowego ${ }^{62}$. Miłosierdzie prawdziwie chrześcijańskie nie może ograniczać się do tzw. uczynków miłosierdzia, sprowadzających się wyłącznie do nieangażujących całej osoby po-

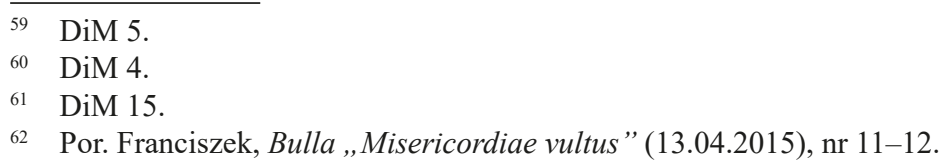


jedynczych aktów świadczenia. Musi być stylem życia, relacją wzajemności, postawą pełną solidarności z potrzebującymi i zaproszeniem do pojednania i wspólnoty. Autentyczne chrześcijańskie miłosierdzie powinno zarazem posiadać ukierunkowanie duszpasterskie i apostolskie. Nie może być traktowane jako dodatek, ale jako istotna funkcja chrześcijaństwa. Miłosierdzie to, choć nastawione głównie na człowieka $\mathrm{w}$ jego doczesnych potrzebach, musi mieć wymiar ponadczasowy, skierowany ku Bogu jako źródłu i celowi wszelkich ludzkich dzieł miłosierdzia ${ }^{63}$.

\section{MIŁOSIERDZIE JAKO STYL ŻYCIA}

Człowiek dociera do miłosiernej miłości Boga, do Jego miłosierdzia o tyle, o ile sam przemienia się wewnętrznie w duchu podobnej miłości w stosunku do bliźnich. Ten najistotniej ewangeliczny proces nie jest tylko jednorazowym przełomem duchowym, ale całym stylem życia, istotną właściwością chrześcijańskiego powołania. Polega ono na stałym odkrywaniu i wytrwałym, pomimo wszystkich trudności natury psychologicznej czy społecznej, urzeczywistnianiu miłości jako sity jednoczacej i dźwigającej zarazem: miłości miłosiernej, która jest ze swojej istoty miłością twórczą ${ }^{64}$.

To zacytowane papieskie wezwanie do przyjęcia miłosierdzia jako stylu życia odpowiada ogólnej koncepcji miłosierdzia w stosunkach międzyludzkich zawartej w encyklice Dives in misericordia. Dotyczy postawy, która odpowiada na potrzeby drugiego człowieka, wychodzi im naprzeciw z uwagi na godność, jaką posiada każda osoba, w tym wypadku potrzebująca pomocy ${ }^{65}$. Nie jest ta postawa aktem jednorazowym. Warto zauważyć, że w encyklice Dives in misericordia Jan Paweł II dla podkreślenia trwałości postawy miłosierdzia użył kilkakrotnie formy niedokonanej czasowników. Stwierdził m.in., że człowiek jest powołany do tego, by sam czynił miłosierdzie, że sam dociera do miłosiernej miłości Boga, gdy przemienia się wewnętrznie w duchu podobnej miłości w stosunku do bliźnich ${ }^{66}$. Człowiek ma być miłosierny, a przymiotnik ten wymaga właśnie trwałości postawy czynienia miłosierdzia w stosunku do bliźnich.

Miłosierdzie jest dojrzałą postawą opartą na braterstwie i solidarności z drugim człowiekiem. Towarzyszy jej przekonanie, że nie tylko świadczący miłosierdzie jest podmiotem miłosierdzia, ale również przyjmujący je. Stąd styl życia miłosierdziem zakłada jego relacyjność i wzajemność: „Jeśli tej dwustronności, tej wzajemności brak, wówczas czyny nasze nie są jeszcze prawdziwymi aktami

\footnotetext{
${ }_{63}$ J. Salij, Kościół owocem Bożego miłosierdzia, w: Tajemnica Bożego miłosierdzia..., s. 89.

64 DiM 14

65 Por. K. Góźdź, Teologia Bożego miłosierdzia, w: Dogmatyka w perspektywie..., s. 299.

66

DiM 14.
} 
miłosierdzia" ${ }^{67}$. W akcie miłosierdzia każda z jego stron jest nim obdarowana. Obdarowanie to stanowi wzrost o to dobro, o które świadczący miłosierdzie wzrósł, które jego samego ubogaciło. Praktyka autentycznego miłosierdzia opartego na wzajemności w stosunkach społecznych, między najbliższymi, przyjaciółmi, w pracy i duszpasterstwie, jest podstawowym warunkiem zapoczątkowania cywilizacji miłości-miłosierdzia.

Styl miłosiernego życia zakłada kierowanie się przebaczeniem. Według Jana Pawła II jest ono dowodem na autentyczne nawrócenie w życiu, a to z kolei jest owocem poznania Boga w Jego ojcostwie. Nawrócenie jako postawa winno być stylem życia każdego chrześcijanina, każdego wezwanego do poznania miłosierdzia Boga i zastosowania go w swoim życiu. Status conversionis jest bowiem postawą domagającą się nieustannie odnowy spojrzenia na świat i drugiego człowieka, stale nowego odkrywania w nim brata i partnera w relacji miłosierdzia ${ }^{68}$. Domaga się wzięcia odpowiedzialności za drugiego człowieka w ramach stosunków społecznych.

\section{CYWILIZACJA MIŁOSIERDZIA}

Ów ludzki świat nie może stawać się bardziej ludzkim, jeśli nie wprowadzimy w wieloraki zakres stosunków międzyludzkich, a także stosunków społecznych, wraz ze sprawiedliwością, owej „miłości miłosiernej”, która stanowi mesjańskie orędzie Ewangelii ${ }^{69}$.

Postulat o zaprowadzenie „cywilizacji miłości”, ku której mają zdążać wszelkie wysiłki w dziedzinie społecznej, politycznej, kulturalnej i ekonomicznej, a która jest synonimem świata „,bardziej ludzkiego”, sformułował już papież Paweł $\mathrm{VI}^{70}$. Magisterium Kościoła wskazuje, że to na nim - nie w kategorii wyróżnienia, ale obowiązku - spoczywa w pierwszej kolejności zadanie rozpoczęcia przemiany oblicza świata. W duchu Ewangelii Kościół ma tworzyć cywilizację miłości miłosiernej. Chrześcijanie winni być miłosierni na wzór Boga Ojca, rozpoczynając trud przemiany świata od przemiany siebie: „Bądźcie miłosierni, jak Ojciec wasz jest miłosierny" (Łk 6,36).

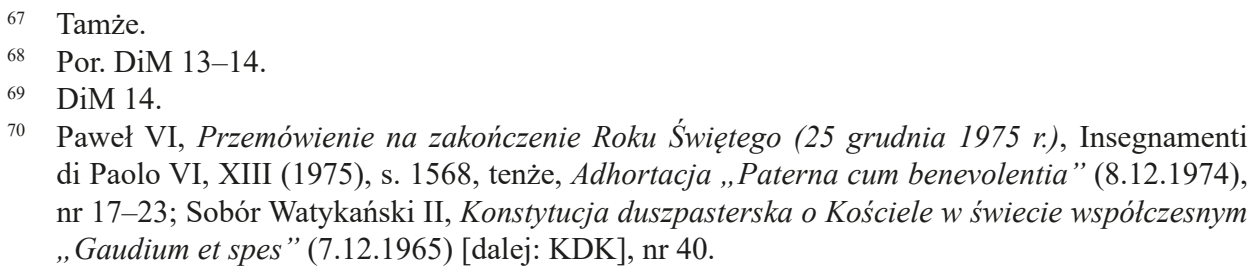

70 Paweł VI, Przemówienie na zakończenie Roku Świętego (25 grudnia 1975 r.), Insegnamenti di Paolo VI, XIII (1975), s. 1568, tenże, Adhortacja „Paterna cum benevolentia” (8.12.1974), nr 17-23; Sobór Watykański II, Konstytucja duszpasterska o Kościele w świecie wspótczesnym „,Gaudium et spes” (7.12.1965) [dalej: KDK], nr 40. 
Kościół i wszyscy jego członkowie naznaczeni znakiem miłosierdzia Boga, świadczący o nim i głoszący je, mają wewnętrzny obowiązek upominać się o prawa i dobro innych. Ta zdecydowana reakcja ma być odpowiedzią zwłaszcza na sytuację ludzi szczególnie doświadczonych przez życie, potrzebujących, cierpiących i uciskanych. Prawdziwe czyny miłosierdzia muszą skutkować podjęciem starań o poszanowanie praw i godności każdego człowieka, o obronę wolności i pokoju oraz sprawiedliwości w stosunkach międzyludzkich. Postawa miłosierdzia domaga się podjęcia odpowiedzialności za los innych, całego świata.

Do podstawowych dokumentów wyrażających troskę Kościoła w tym zakresie należy m.in. encyklika Jana XXIII Pacem in terris z 1963 roku, w której papież dał wyraz przekonaniu o niezbywalnej godności człowieka jako rozumnej osoby, o jego prawach, w tym prawie do wolności sumienia i wyznania, i w której prekursorsko zaznaczył znaczenie miłości uzupełniającej i ożywiającej sprawiedliwość ${ }^{71}$. Następnym dokumentem jest posoborowa encyklika Pawła VI Populorum progressio z 1967 roku, w której papież podkreślił znamienne dla zasady miłosierdzia w stosunkach międzyludzkich braterstwo oraz koncentrację wysiłków społecznych wokół osoby człowieka, a nie dóbr doczesnych ${ }^{72}$. Sobór Watykański II w konstytucji duszpasterskiej o Kościele wspomniał o konieczności budowania świata opartego na prawdzie, sprawiedliwości i ożywianego miłością ${ }^{73}$.

W ocenie Jana Pawła II ułomności ludzkiej cywilizacji są wynikiem grzechu. Grzech natomiast można zwalczyć jedynie miłością. Stąd potrzebna jest postawa przebaczenia i nawrócenia: „Tak więc podstawowa struktura sprawiedliwości wkracza zawsze na obszar miłosierdzia. To ostatnie posiada jednakże moc wypełnienia sprawiedliwości nową treścią. Treść ta najpełniej uwydatnia się w przebaczeniu"74. Postawa permanentnego nawrócenia gwarantuje dojrzałość w ofiarowywaniu i przyjmowaniu przebaczenia, a co za tym idzie wzrastaniu w postawie pojednania. Przywrócenie jedności między ludźmi może się dokonać jedynie w Chrystusie, który przez Ducha Świętego dokonuje wewnętrznego odnowienia, odrodzenia i zespolenia ludzi w jedną rodzinę przybranych braci i sióstr. Tym samym Jan Paweł II, zachowując koncepcję cywilizacji opartej na miłości Pawła VI, dookreślił tę miłość jako miłosierną. Jest ona celem, do którego winny zmierzać wszystkie wysiłki w każdej dziedzinie życia ludzkości, a przede wszystkim

71 Jan XXIII, Encyklika „Pacem in terries” (11.04.1963), nr 35

72 Paweł VI, Encyklika „Populorum progressio” (26.03.1967), nr 73; por. DiM 14.

73 KDK 26; A.L. Szafrański, Ku cywilizacji miłości miłosiernej, w: Mitosierdzie w postawie ludzkiej, red. W. Słomka, Lublin 1989, s. 255-267.

74 DiM 14; Jan Paweł II, Przebacz a zaznasz pokoju. Orędzie na Światowy Dzień Pokoju 1997, nr 1, w: Ojciec Święty Jan Paweł II. O przebaczeniu i pojednaniu, Kraków 2000, s. 16. 
Kościoła $^{75}$. Ze względu na nią ludzkość winna wyrzec się chęci odwetu, a skoncentrować na autentycznej więzi z każdym człowiekiem ${ }^{76}$.

\section{POJEDNANIE CELEM MIŁOSIERDZIA}

Tak więc podstawowa struktura sprawiedliwości wkracza zawsze na obszar miłosierdzia. To ostatnie posiada jednakże moc wypełnienia sprawiedliwości nową treścią. Treść ta najprościej i najpełniej uwydatnia się w przebaczeniu. Ono bowiem ukazuje, iż poza całym procesem „wyrównawczym” czy też „rozejmowym”, który właściwy jest dla samej sprawiedliwości, dochodzi do głosu miłość, czyli afirmacja człowieka ${ }^{77}$.

W adhortacji apostolskiej Reconciliatio et paenitentia Jan Paweł II podkreślił, że pojednanie jest miłosiernym darem Boga dla człowieka, a historia zbawienia jest „przedziwną historią pojednania, w której Bóg, jako Ojciec, przez Krew i Krzyż swego Wcielonego Syna pojednał z sobą świat, rodząc w ten sposób nową wspólnotę pojednanych"78. Dzieło pojednania swoje źródło znajduje w zasługach Chrystusowych, zwłaszcza w Jego śmierci i zmartwychwstaniu. To tam Bóg ostatecznie pojednał świat ze sobą, o czym przypomina formuła rozgrzeszenia w sakramencie pokuty ${ }^{79}$.

We wskazanych dokumentach podkreślono, że pojednanie ma swoje źródło w miłosierdziu Ojca, wychodzi z Jego inicjatywy, a urzeczywistnia się przez Jezusa Chrystusa. Szczególnie wyraźnie zostało to zobrazowane w analizie przypowieści o synu marnotrawnym, którą odnajdujemy i w Dives in misericordia, i w Reconciliatio et paenitentia ${ }^{80}$. W pojednaniu człowieka z Bogiem szczególną rolę odgrywa Duch Święty. To on pobudza do przygotowania się do sakramentu pojednania, wznieca skruchę i zdolność odkrycia swego stanu w świetle wiary i miłosierdzia Bożego. Pojednanie z Bogiem sprawia, że wierzący ponownie otrzymuje Ducha, a wraz z Nim wszelkie nadprzyrodzone dary ${ }^{81}$.

Miłosierdzie Boże, najdoskonalej okazane ludziom w Chrystusie i Jego dziele zbawczym, uobecnia teraz Kościół, któremu zlecił On posługę jednania ${ }^{82}$.

5 T. Styczeń, Miłość a sens życia. Nad encyklika Jana Pawła II „Redemptor hominis”, w: Jan Pawet II. Redemptor hominis. Tekst i komentarze, red. Z.J. Zdybicka, Lublin 1982, s. 89-110.

76 A.L. Szafrański, Ku cywilizacji..., s. 255-267.

77 DiM 14.

$78 \quad \operatorname{ReP} 4$.

79 OP 46

$80 \quad$ DiM 5, 13; $\operatorname{ReP} 4,6,7 ;$ OP 5, 19.

81 OP 51 B; C. Krakowiak, Miłosierdzie Boże w liturgii..., s. 210-211.

82 DiM 13; OP 6. 
Oryginalność i charyzmat Kościoła na tym polu przejawia się w sięganiu do tego, co spowodowało rozdarcie pierwotne, tj. do grzechu. „Pełne pojednanie jednak wymaga koniecznie uwolnienia od grzechu, który musi być całkowicie wykorzeniony. A zatem ścisła wewnętrzna więź głęboko łączy nawrócenie i pojednanie"»3. Misja Kościoła urzeczywistnia się najpełniej w posłudze sakramentem pokuty i pojednania.

$\mathrm{Na}$ mocy powierzonego mu zadania Kościół służy grzesznikom pojednaniem nie tylko w stosunku do nich samych czy też do Boga, ale również w stosunku do siebie samego. Na mocy chrztu każdy wierzący został włączony w Kościół - Mistyczne Ciało Chrystusa, a każdy grzech skutkuje powstaniem w ramach tego organizmu rany, rozdarcia, domagających się pojednania ${ }^{84}$. Pojednanie obejmuje nie tylko Kościół ziemski, ale nade wszystko Kościół chwalebny: „W tajemnicy Świętych Obcowania to powszechne pojednanie urzeczywistnia się w sposób najgłębszy i najbardziej owocny dla wspólnego zbawienia" ${ }^{85}$.

Pojednanie z Kościołem jest konieczne także ze względu na społeczny wymiar grzechu, który nie tylko obraża Boga, ale przynosi szkodę Kościołowi. Grzech ciężki zmienia bowiem stosunek poszczególnych wiernych do Kościoła. Kto ciężko zgrzeszył, należy do Kościoła jedynie ciałem, lecz nie należy do niego sercem, gdyż nie ma Ducha Chrystusowego, tj. łaski chrzcielnej, która włącza w Kościół i czyni jego żywym członkiem. Prawdziwe pojednanie z Bogiem musi się więc łączyć z pojednaniem z Kościołem, czyli ze wszystkimi braćmi ${ }^{86}$.

Doświadczenie pojednania z Bogiem, sobą samym i Kościołem poprzez uzyskanie przebaczenia i doświadczenie miłosierdzia Bożego wyzwala pragnienie pojednania z każdym człowiekiem. Pojednanie z ludźmi rozpoczyna się od przekazywania im daru przebaczenia i skutkuje nawiązaniem zerwanych więzi oraz umocnieniem pokoju ${ }^{87}$.

Jedność między ludźmi natomiast jest możliwa jedynie wtedy, gdy każdy z nich z osobna spotka się z miłosierdziem Bożym i osobiście się nawróci. „Osobiste nawrócenie jest konieczną drogą do zgody pomiędzy ludźmi"»8.

\footnotetext{
$83 \quad \operatorname{ReP} 4$.

84 OP 4; KK 11.

$85 \quad \operatorname{ReP} 12$.

86 OP 5, 13; C. Krakowiak, Miłosierdzie Boże w liturgii..., s. 211-212.

87 DiM 14. W bulli Aperite portas Redemptori (6.01.1983) Jan Paweł II pisał m.in., że obchody Roku Jubileuszowego (wówczas w rocznicę 1950-lecia odkupienia Pańskiego) osiągną swój cel, jeżeli przekształcą się w wysiłek pojednania między uczniami Chrystusa oraz pomiędzy wszystkimi ludźmi (nr 93).

88

$\operatorname{ReP} 4$.
} 


\section{STRESZCZENIE}

Jak wskazano we wstępie, celem niniejszego artykułu była prezentacja wybranych zagadnień dotyczących eklezjalnego i społecznego wymiaru miłosierdzia w nauczaniu Kościoła, głównie pontyfikatu Jana Pawła II, jako odpowiedzi na zanikanie więzi braterstwa między ludźmi i sposobu na odbudowanie relacji. Wywód został oparty na trzech filarach: 1) ukazania miłosierdzia Bożego w sakramentach (poprzez sakramentalność Kościoła, w sakramencie Eucharystii oraz pokuty i pojednania), 2) przedstawienia zagadnienia "wyobraźni miłosierdzia” (w temacie solidarności z potrzebującymi, relacyjności miłosierdzia oraz relacji „miłosierdzie”-,,sprawiedliwość”), 3) ukazania kwestii czynów miłosierdzia (poprzez miłosierdzie jako styl życia, ideę cywilizacji miłosierdzia oraz pojednania jako celu posługi miłosierdzia).

Wnioski wskazują, że aktualność misji Chrystusowego Kościoła i potrzeba jego istnienia we współczesnym świecie zależą w dużym stopniu od podjęcia przez niego wezwania zawartego w Ewangelii Chrystusa: „Bądźcie miłosierni, jak Ojciec wasz jest miłosierny" (Łk 6,36). Przykład dawany przez Kościół ma stać się zaczynem świata opartego na autentycznej solidarności międzyludzkiej. Czyny miłosierdzia i jego postawa, odpowiadające na sygnały prawidłowo ukształtowanej wyobraźni, są jedynym sposobem na zbudowanie świata prawdziwie ludzkiego.

Kształt posługi Kościoła winien odzwierciedlać poziom autentyczności wiary członków Kościoła w miłosierdzie Boże i doświadczania go. Kościół dostrzega, że praktykowana przez niego posługa bycia znakiem i „sakramentem” Bożego miłosierdzia jest w istocie najlepszą propozycją dla "odnowy oblicza” dzisiejszego świata. Zadaniem Kościoła jest ukazanie prawdziwego znaczenia pojęcia „miłosierdzie”, które w postawie ludzkiej odzwierciedla doskonałość Boga, wypełniając treść sprawiedliwości i stanowiąc propozycję stylu życia.

\section{BIBLIOGRAFIA}

Balter L., Kościót jako „sakrament” Miłosierdzia Bożego, w: W Miłosierdziu Bożym ku nowej ewangelizacji. V Kongres ku czci Milosierdzia Bożego. 9-11 kwietnia 1999, Częstochowa - Dolina Mitosierdzia - Księża Pallotyni, Ząbki 1999, s. 17-37.

Balter L., Kościót jako sakrament Bożego milosierdzia, Kolekcja Communio 15, red.

L. Balter, S. Dusza, A. Piętka, Poznań 2003, s. 151-173.

Benedykt XVI, Encyklika ,Deus caritas est” (25.12.2005).

Benedykt XVI, Eucharystia musi być centrum waszego życia. 21 sierpnia. Msza św. na zakończenie Światowego Dnia Młodzieży, L'Osservatore Romano [wyd. polskie] 26,10 (2005), s. 26-28. 
Benedykt XVI, Orędzie na Wielki Post 2006, https://opoka.org.pl/biblioteka/ W/WP/benedykt_xvi/przemowienia/wpost2006kep_29092005.html (dostęp: 15.04.2019).

Brzozowski M., Kościół wyznaje miłosierdzie Boga i głosi je, w: Jan Paweł II. Dives in misericordia. Tekst i komentarze, red. S. Nagy, Lublin 1983, s. 183-188.

Czego nie wiemy o miłosierdziu? Z ks. Tomaszem Węcławskim rozmawia Łukasz Tischner, Znak 54,3 (2003), s. 36-49.

Eucharystia sakrament nowego życia. Oficjalny dokument Papieskiego Komitetu Obchodów Wielkiego Jubileuszu roku 2000, red. Komisja Teologiczno-Historyczna Wielkiego Jubileuszu Roku 2000, Katowice 2000.

Franciszek, Bulla „Misericordiae vultus” (13.04.2015).

Góźdź K., Teologia Bożego miłosierdzia, w: Dogmatyka w perspektywie Bożego miłosierdzia, red. K. Góźdź, K. Guzowski, Lublin 2010, s. 287-302.

Greniuk F., Miłosierdzie Boże w sakramencie pojednania, w: Jan Pawet II. Dives in misericordia. Tekst i komentarze, red. S. Nagy, Lublin 1983, s. 189-204.

Jan Paweł II, Jesteście na wagę złota. Słowa Jana Pawła II przed katedra, Częstochowa 6 czerwca 1979 r., Chrześcijanin w Świecie 11,8 (1979), s. 134-135.

Jan Paweł II, Pochylać się nad cierpiacym człowiekiem. Anioł Pański, 24 sierpnia 1980 r., w: Krzyż znakiem naszej wiary i nadziei. Jan Pawet II o cierpieniu Chrystusa i człowieka. 1978 - szesnasty października - 1986, red. W. Murawiec, M. Rudyk, Kalwaria Zebrzydowska 1986, s. 237.

Jan Paweł II, Encyklika „Dives in misericordia” (30.11.1980).

Jan Paweł II, Solidarność z Chrystusem cierpiacym. Przemówienie do Kolegium Kardynatów Kurii Rzymskiej z dnia 23 grudnia 1982 r., w: Krzyż znakiem naszej wiary i nadziei. Jan Pawet II o cierpieniu Chrystusa i człowieka. 1978 - szesnasty października - 1986, red. W. Murawiec, M. Rudyk, Kalwaria Zebrzydowska 1986, s. 172.

Jan Paweł II, Bulla ,Aperite portas Redemptori” (6.01.1983).

Jan Paweł II, Cierpienie nie jest nigdy bezużyteczne. Homilia z dnia 3 września 1983 r. ze szpitala Villa Albani, L'Osservatore Romano [wyd. polskie] 4,9 (1983), s. 27.

Jan Paweł II, Adhortacja „Reconciliatio et paenitentia” (29.10.1983).

Jan Paweł II, List apostolski ,, Salvifici doloris” (11.02.1984).

Jan Paweł II, Encyklika „Dominum et vivificantem” (18.05.1986).

Jan Paweł II, Przebacz a zaznasz pokoju. Orędzie na Światowy Dzień Pokoju 1997, w: Ojciec Święty Jan Pawet II. O przebaczeniu i pojednaniu, Kraków 2000, s. 16-28. Jan Paweł II, Bulla „Incarnationis mysterium” (29.11.1998).

Jan Paweł II, Kontemplujmy przykład Jezusa - Boskiego Samarytanina. Orędzie na VIII Światowy Dzień Chorego 2000 r., (6.08.1999), https://opoka.org.pl/biblioteka/W/WP/ jan_pawel_ii/przemowienia/chory2000_06081999.html (dostęp: 30.12.2019).

Jan Paweł II, Sakrament spowiedzi darem miłosierdzia Bożego. Przesłanie papieskie do kard. Williama Wakefielda Bauma, L'Osservatore Romano [wyd. polskie] 21,6 (2000), s. 5-7. 
Jan Paweł II, List apostolski „Novo millennio ineunte” (6.01.2001).

Jan Paweł II, List do kapłanów na Wielki Czwartek roku 2001.

Jan Paweł II, List do kapłanów na Wielki Czwartek roku 2002.

Jan Paweł II, Encyklika „Ecclesia de Eucharistia” (17.04.2003).

Kowalczyk M., Sakramentologia, w: Dogmatyka w perspektywie Bożego miłosierdzia, red. K. Góźdź, K. Guzowski, Lublin 2010, s. 199-222.

Krakowiak C., Miłosierdzie Boże w liturgii sakramentu pojednania, w: Jan Pawet II. Dives in misericordia. Tekst i komentarze, red. S. Nagy, Lublin 1983, s. 205-214.

Lekan J., Przebaczenie w optyce miłosierdzia, Teologia w Polsce 10,2 (2016), s. 59-77.

Mojek S., Miłosierdzie Boże w sprawowaniu sakramentu pojednania, w: Miłosierdzie w postawie ludzkiej, red. W. Słomka, Lublin 1989, s. 129-134.

Nowak J., Podstawy , wyobraźni miłosierdzia” w nauczaniu Ojca Świętego Jana Pawła II, Ruch Biblijny i Liturgiczny 2 (2006), s. 125-137.

Obrzędy sakramentu pokuty, 2.12.1973.

Padewski S., Droga Kościoła - droga miłosierdzia, w: Tajemnica Bożego miłosierdzia w charyzmacie mariańskim, red. J. Kumala, Licheń 2004, s. 93-112.

Paweł VI, Encyklika „,Mysterium fidei” (3.09.1965).

Paweł VI, Adhortacja „Paterna cum benevolentia” (8.12.1974).

Paweł VI, Przemówienie na zakończenie Roku Świętego (25 grudnia 1975 r.), Insegnamenti di Paolo VI, XIII (1975), s. 1568.

Płużek Z., Miłosierdzie w postawie ludzkiej w interpretacji psychologicznej, w: Miłosierdzie w postawie ludzkiej, red. W. Słomka, Lublin 1989, s. 249-254.

Ryczan K., Miłość-miłosierdzie w życiu społecznym, w: Jan Pawet II. Dives in misericordia. Tekst i komentarze, red. S. Nagy, Lublin 1983, s. 223-234.

Salij J., Kościół owocem Bożego miłosierdzia, w: Tajemnica Bożego miłosierdzia w charyzmacie mariańskim, red. J. Kumala, Licheń 2004, s. 89.

Słomka J., Boże miłosierdzie, Gość Niedzielny 80,17 (2003), s. 9.

Sobór Watykański II, Konstytucja o Liturgii Świętej ,, Sacrosanctum concilium ”(6.12.1963).

Sobór Watykański II, Konstytucja dogmatyczna o Kościele „Lumen gentium”(21.11.1964).

Sobór Watykański II, Konstytucja duszpasterska o Kościele w świecie współczesnym „, Gaudium et spes” (7.12.1965).

Styczeń T., Miłość a sens życia. Nad encyklika Jana Pawła II „Redemptor hominis”, w: Jan Pawet II. „, Redemptor hominis”. Tekst i komentarze, red. Z.J. Zdybicka, Lublin 1982, s. 89-110.

Szafrański A.L., Ku cywilizacji miłości miłosiernej, w: Miłosierdzie w postawie ludzkiej, red. W. Słomka, Lublin 1989, s. 255-267.

Tischner J., Drogi i bezdroża miłosierdzia, Kraków 2001.

Warzeszak J., Papież Franciszek świadkiem Bożego miłosierdzia, Warszawskie Studia Teologiczne XXIX,4 (2016), s. 36-74. 
Słowa kluczowe: miłosierdzie, oikonomia, sakramenty, wyobraźnia miłosierdzia, przebaczenie, pokuta, Kościół

\section{MERCY AS OIKONOMIA OF THE CHURCH. BASED ON THE EXAMPLES OF MAGISTERIUM ECCLESIAE}

\section{Summary}

As it was mentioned in the first part of the present article, its purpose was the presentation of the selected issues concerning the ecclesiological and social aspect of mercy in the teaching of the Church, mainly of the pontificate of pope John Paul II, as the answer to the disappearing of the bond of brotherhood among people and the way of the restoration of relation. The study was leant on three pillars (problems): 1) God's mercy in sacraments (through the sacramentalness of the Church, in the Eucharist and the sacrament of penance and reconciliation), 2) the issue of "creativity in charity" (through support for needy people, relationality of mercy and the relation between "mercy" and "justice"), 3) deeds of mercy (through mercy as a life style, the idea of the civilization of mercy and reconciliation as the purpose of the service of mercy).

Summarizing the presented observation, it must be said that the validity of Christ's Church mission and the necessity of its existence in the modern world depend largely on the undertaking of the adjuration contained in Christ's Gospel: "Be merciful, just as your Father is merciful" (Luke 6:36). The example given by the Church is to become the leaven of the world based on authentic interpersonal solidarity. The act of mercy creates harmony and unity amongst people, building a better world.

The service of the Church should reflect on the level of authentic faith in God's mercy - for the members of the Church to experience it. God's mercy brings renewal of the earth. The duty of the Church is to show the true meaning of "mercy" that reflects in the human attitude God's perfection, fulfilling justice and to lead a better life.

Keywords: mercy, oikonomia, sacraments, creativity in charity, forgiveness, atonement, Church 